\title{
An ERP study of kind-denoting nouns in subject position in Brazilian Portuguese
}

\section{Um estudo neurofisiológico de nomes que denotam tipo na posição de sujeito em português brasileiro}

\begin{abstract}
Aniela Improta França
Universidade Federal do Rio de Janeiro, Rio de Janeiro, Rio de Janeiro / Brasil aniela@gmail.com

Maurício Cagy

Universidade Federal do Rio de Janeiro, Rio de Janeiro, Rio de Janeiro / Brasil mauricio.cagy@gmail.com

Antonio Fernando Catelli Infantosi

Universidade Federal do Rio de Janeiro, Rio de Janeiro, Rio de Janeiro / Brasil mcagy@peb.ufrj.br
\end{abstract}

Resumo: A referencialidade é um tópico que sempre renova o interesse da linguística teórica e experimental. Isso porque as referências são recursos fundamentais das línguas naturais que estabelecem uma relação entre a língua no cérebro e as coisas do mundo lá fora. Este experimento investiga duas condições referentes a mecanismos de referencialidade: uma relaciona-se a um NP não específico na posição do sujeito e a outra se relaciona a um NP que denota tipo influenciado por um contexto especial de Conhecimento do Mundo. A comparação entre as duas condições nas suas versões congruente e incongruente revelou que a Condição do Conhecimento do Mundo apresentou um ERP $\left(\mathrm{N}_{400}\right)$ com latência mais curta. Já que as sentenças são percebidas em uma ordem linear e que o sujeito em português (língua SVO) vem na frente, aqui se propõe que o acesso ao sujeito pragmaticamente saliente na sua posição sentença-inicial abre, logo de início, uma moldura pragmática e pode 
restringir a seleção no verbo-complemento, fazendo com que o merge verbo-objeto se dê de forma mais rápida. Isso pode explicar porque o $\mathrm{N}_{400}$ relacionado aos estímulos do Conhecimento do Mundo apareceu mais cedo do que na Condição de Controle. Adicionalmente, encontrouse um ERP positivo em torno dos $600 \mathrm{~ms}$ apenas presente nos estímulos da Condição de Conhecimento do Mundo e ausente na Condição de Controle. A interpretação deste achado é que o pleno acesso ao conteúdo pragmático que está no sujeito só ocorre após o merge do complemento ao verbo.

Palavras-chave: hipótese sintaxe-primeiro; pragmática no processamento de sentenças; extração de potenciais relacionados a evento; $\mathrm{N}_{400}-\mathrm{P}_{600}$.

Abstract: Referring is a permanently hot topic in theoretical and experimental linguistics since references establish the fundamental relationship between parts of language in the brain and things out there in the world. This experiment investigates two conditions pertaining to reference mechanisms: one relates to a generic NP in the subject position and the other to an NP that is influenced by a special World Knowledge context. The comparison between the two conditions in their congruous and incongruous versions depicts a shorter latency for the $\mathrm{N}_{400}$ ERPs of the World Knowledge stimuli. Since linguistic input gradually reaches the reader from left to right, we propose that the access to a pragmatically salient subject in its sentence-initial position, by opening a window into World Knowledge, may restrict selections in the verb-complement merge more speedily than pragmatically unmarked subjects. This may explain why the $\mathrm{N}_{400}$ related to the World Knowledge stimuli appeared earlier than that of the Control Condition. Additionally, we found a later positive ERP around the $600 \mathrm{~ms}$ only present in the World Knowledge stimuli and absent in the Control condition. The interpretation of this finding is that full access to the pragmatic contents of the subject only takes place after the verb complement merge.

Keywords: syntax-first hypothesis; pragmatics in sentence processing; event-related brain potentials; $\mathrm{N}_{400}-\mathrm{P}_{600}$.

Recebido em: 5 de janeiro de 2017

Aprovado em: 10 de abril de 2017 


\section{Introduction}

Referring is a permanently hot topic in theoretical and experimental linguistics, since it takes the fundamental role of establishing a relationship between parts of language in the brain and things out there in the world.

Referring can take place in a number of ways. Typically, a referential expression (RE) is a Noun $(\mathrm{N})$ that successfully picks out a definite referent in the world because the words in the expression and the way they are combined produce an accurate description of such referent, in such a way that the hearer of the expression can recognize the speaker's intention. (HAVILAND; CLARK, 2002; CLARK; SENGUL, 1979).

Notice, for instance (i) and (ii).

(i) The dentist pulled the tooth easily

(ii) Donald pulled the tooth easily

In (i), the noun dentist activates a specific piece of structured encyclopedic knowledge which is inextricably connected with that linguistic RE. Contrastingly, in (ii), out of a specific context or deitic situation, Donald is an RE that conveys poorer content, since it picks out any human being in the world to refer, just based on gender and number traces. Thus, this not-specific Donald exerts less attractive power in relation to pull and tooth than the dentist, because the latter is a kind-denoting RE.

But if the nouns in the subject position in (i) and (ii) are REs of different nature, it is important to verify how such contrasting nouns, respectively semantically rich and poor, might impact the online processing of these sentences.

At this point, holding minimal assumptions about on-line comprehension, it is safe to say that we parse an acoustic stream into discrete units that come into our ears incrementally. So, necessarily, part of the task is to identify the onset of each new syllable and combine syllables into words, phrases and sentence. As of the identification of the first words, there is profuse evidence that we take a very active, or better, proactive step in trying to anticipate incoming material, so that incoming items can, without a delay, be represented and incorporated into existing representations (SCHUBERTH; EIMAS, 1977; STANOVICH; WEST, 
1981; ALTMANN; STEEDMAN, 1988; ALTMANN; KAMIDE, 1999; FEDERMEIER, 2007; ITO et al., 2016; FREUNBERGER; ROEHM, 2016).

So, beyond the phonemic identification, during language processing, perceivers have a range of data at their disposal that they process on the fly: knowledge about the formal properties of language, semantic knowledge about contents and maybe even knowledge about pragmatics. But at what speed? What kicks in first? Does processing follow the linear acoustic or visual input order only or is it subject to a non-linear algorithm? Predictions depend on one's theoretical standing.

For instance, under a syntax-first account, inspired by the Minimalist framework (CHOMSKY, 1993), the assumption is that before any sentential meaning can be achieved, there is necessarily an intricate formal algorithm that secures structural hierarchy whirling around the $\mathrm{vP}$, that includes the merge between the internal argument and the verb first. In this account, which is explicitly derivational, the sentence is built from the bottom up, bit by bit. Thus, since processing is incremental, in an SVO language, for a split of second, this syntax algorithm would make the listener ignore the noun that reached the ears and was perceived first, be it the dentist or Donald, to start work on the verb and its internal argument. Then the complete vP can license the external argument and merge with it. So, pulled the tooth is OK and needs an agent that can be the dentist or a human named Donald. Thus, the functional elements within the vP would be checked first, and the syntactic operations should be momentarily blind to the root content of the noun in the subject position regardless of its referential nature (CHOMSKY, 1998). In this view, the pragmatic frame deployed by the root of dentist would not be explored in the same time window as the one that applies to the $\mathrm{vP}$, which is explored first (GOMES, 2014).

Contrastingly, taking a cognitivist, pragmatic approach to how sentential meaning is attained, Fillmore $(1982,2007)$ advances that REs like dentist are qualitatively special because they are semantically rich and they immediately activate a private history of that concept in the hearer's brain. This frame encompasses a coherent structure of related concepts, such as pull and tooth, that get combined by attraction of frequent use together. Thus, a frame would entail a net of facts about our world knowledge (WK) that can be retrieved from memory and that 
refers to an entity kind, in this case that of a human being who works taking care of someone else's teeth.

Under the semantic-first account, the predictions would be that when processing starts, due to the pressure for fast linguistic decisionmaking, frugal heuristics takes place and the pragmatic frame deployed by the semantic content in the roots of dentist, pull and tooth is explored first. For these theories, the content of such roots is immediately inspected and suffers attraction, rejection and other surface effects that ultimately motivate syntax (KOS et al., 2010; KIM; OSTERHOUT, 2005; KUPERBERG et al., 2007; CHOW; PHILIPS, 2013).

The big question is to decide which account is closest to the neurophysiological reality of such cognitive computations. When are these pieces of knowledge triggered and what triggers them - syntax, semantics or pragmatics - to be used online while processing language in the brain? How do these pieces of knowledge interact toward the final understanding of the sentence? What constraint is satisfied first?

In order to investigate these complex issues affecting the rapid online integration of syntax, semantic and world knowledge information, we built an online investigation of Brazilian Portuguese sentences using a useful technique in neuroscience of language. It is the event-related brain potential (ERP): the extraction, from the electroencephalogram (EEG) recording of raw brain activity, of the clean electrical potentials specifically related with the brain activity one wants to study, in this case, language processing. The technique consists of time-locking a target linguistic unit to the corresponding EEG signal emitted by the participant's brain. With this time-locking procedure it became possible to pinpoint the exact instant that the target linguistic stimulus was presented to the volunteer and the exact time it provoked a reaction (the cortical response) related to that part of the stimulus (cf. KUTAS; HILLYARD, 1980; KUTAS; HILLYARD, 1984; KUTAS et al., 1984, FRIEDERICI, 1995; LAGE, 2005; LI; YANG; HAGOORT, 2008).

For our basic comparison, we contrasted two conditions: Condition 1: World Knowledge (WK) sentences, like those in (i); and Condition 2: Control Sentences (CT) like in (ii). Thus, our objective is to time in milliseconds the impact that a kind-denoting noun in the subject position of our WK condition compared to a non-specific one of our CT condition will pose on the course of processing, just as it reaches the object. 
We are embracing the syntax-first hypothesis that supports a single processing stream, syntax all the way down. (GOUVEA, 2010; GOMES, 2014; GOMES, FRANÇA, 2015; STOCKALL; MARANTZ, 2006; PHILLIPS; LEWIS, 2009; LAU et al., 2006). If this hypothesis is correct, the special content of a kind denoting noun in the subject position should not hasten processing, since, at first, the semantic content of the noun in the subject position would not be inspected. As we shall see, this prediction bears interesting connections with neurophysiological markers for semantic congruence in the ERP literature and motivated the two additional conditions that we inserted in this test.

During the first thirty years of linguistic ERP research since the 80's, among the most commonly extracted ERP waves were those related to the semantic violations coinciding with the merge operation between the verb and its complement. The usual paradigms stimulate participants with sentences that contrast minimally as to congruence like in (iii) and (iv):

(iii) John ate the sandwich yesterday

(iv) John ate the sandal yesterday

Experimenters most commonly set the trigger for the stimulation point immediately after the verb and measure the ERP at that point, which relates to the exposure to the object. The literature shows that ERP peak amplitudes related to (iv) are higher than those related to (iii) and the difference between the two is statistically significant (KUTAS; HILLYARD, 1980; KUTAS, HILLYARD, 1984; HOLCOMB; NEVILLE, 1991, FRANÇA et al., 2004). Usually the interpretation is that sandals is incongruous in the context of eat and therefore integration efforts result in augmented ERP amplitudes.

This very robust phenomenon, consistently tested across over 100 languages, can be described as an enlarged negative-going eventrelated potentials (ERP), peaking at around $400 \mathrm{~ms}$ post-stimulus: the $\mathrm{N}_{400}$. The cortical reaction to such sentences has been widely described as a consequence of an increased difficulty in morpho-syntactic integration due to the fact that the semantic features of the noun cannot be integrated with the event the requirements set by the verb. The current study will also build on this legacy by proposing two additional conditions, presented in (iv) and (v) as Conditions 3 and 4. These are incongruous versions of Conditions 1 and 2 . 
(v) The dentist pulled the thunder easily

(vi) Donald pulled the thunder easily

Since ERPs are very sensitive to incongruous conditions, this well-tested congruence contrast for the N400 response was included in our test hoping it might interact with contextual or pragmatic data built-in via the subject, promoting an even more amplified ERP response that could discriminate better among conditions. Thus, crossing the two conditions relating to the subject semantics (world knowledge and control) with the two congruity versions (congruous and incongruous) we arrived at 4 conditions, that can be depicted in Table 1.

TABLE 1 - An example of a set of experimental stimuli in the four experimental conditions to be applied within-subject

\begin{tabular}{|l|l|}
\hline \multicolumn{1}{|c|}{ Conditions } & \multicolumn{1}{|c|}{ Sentences } \\
\hline Control Congruous (CTCC) & $\begin{array}{l}\text { O Maurício tirou o dente com facilidade } \\
\text { Maurício pulled the tooth easily }\end{array}$ \\
\hline Control Incongruous (CTIC) & $\begin{array}{l}\text { O Maurício tirou o trovão com facilidade } \\
\text { Maurício pulled the thunder easily }\end{array}$ \\
\hline World Knowledge Congruous (WKCC) & $\begin{array}{l}\text { O dentista tirou o dente com facilidade } \\
\text { The dentist pulled the tooth easily }\end{array}$ \\
\hline World Knowledge Incongruous(WKIC) & $\begin{array}{l}\text { O dentista tirou o trovão com facilidade } \\
\text { The dentist pulled the thunder easily }\end{array}$ \\
\hline
\end{tabular}

We devised an experimental approach to compare sentences that are exactly the same in all their syntactic aspects, but that have semantically rich and poor REs in the subject position and congruous or incongruous nouns in the object position. Notice the stimuli in the four conditions have identical syntactic configurations: [subject [verb-object]], despite the fact that those in WK condition include world knowledge scenarios, and those in the Control condition that have a poor content $\mathrm{RE}$ in the subject position.

Thus, most crucially, exploring the predictions supposedly held by the Semantic-first account, if there is immediate inspection of the content of the noun in the subject position, CTCC should get a greater latency effect than WKCC. For instance, under this hypothesis, in stimulus 1, the world knowledge information inserted in the subject 
dentist should narrow down the list of candidates for pull and the checking of the best candidate, tooth, should hasten the low amplitude N400 that will be formed after the verb.

Concerning the two incongruous conditions - CTIC and WKIC - the incongruence effect measured by the amplitude of the N400 should be enlarged in WKIC when compared with that in CTIC, due to the frustrated anticipation for a specific, focalized noun in the object position: in WKIC instead of the very predictable tooth the participant gets thunder. In CTIC, after pull, predictions include anything that can be pulled, so this unfocused, widespread activation of many candidates should soften the impact of incongruous thunder while enlarging its latency.

Contrastingly, under the perspective of Syntax-first approach, CTCC and WKCC should be exactly the same: the first noun comes in but it should not be fully inspected semantically. Then, when the verb pull comes in, there is anticipation for a large number of possible complements and among them, one is tooth. So, when the object comes and is semantically interpreted in both congruous conditions, it is judged as a compatible complement and the cortical reaction that derives from the integration of the verb and its complement should be a small amplitude $\mathrm{N}_{400}$.

Again, under Syntax-first, CTIC and WKIC should be the same, since there is no special semantic contribution coming from the subject. So, the verb pull should elicit anticipation for a large number of possible complements and thunder is not among them. So, when the object comes in, it should be semantically interpreted and judged as incompatible with the verb and the integration efforts are supposed to cause a cortical reaction of a high amplitude $\mathrm{N}_{400}$, the classical incongruence effect.

\section{Materials and methods}

This EEG-ERP test in its final configuration ${ }^{1}$ was approved by the Ethics Committee of the University Hospital of the Federal University

\footnotetext{
${ }^{1}$ An early version of this test was applied in 2006, and was registered as a work in progress in a non-commercial CD, internally distributed to the members of "GT de Psicolinguística da Anpoll". The idea of the CD, organized by Marcus Maia and Ingrid Finger, was to increase the synergy among the group members of the GT by presenting their on-going, unfinished research. The version presented here includes 10 more participants, a revision of the stimuli and a full digestion of the findings.
} 
of Rio de Janeiro, under the registration \#113.05 (CEP - HUCFF/ UFRJ). ${ }^{2}$ This committee also approved an informed consent form, that experimenters handed in to each participant prior to the beginning of the test. The form explained the methodology, its marginal risks and emphasized the fact that the participant may quit the test at any moment, and that no questions would be asked. The form was signed by all participants who took the test.

\subsection{Participants and stimuli}

While monitored by a 20 channel EEG, 34 right-handed participants (13 males) engaged in a computerized grammaticality judgment test. All participants were within the 18-39-age bracket (cf. Figure 1). Their mean age was 25.9 years (standard deviation, 3.0). All of them had a college education (complete or partial) and were previously screened for systemic diseases and for the current use of antidepressants and had normal or corrected-to-normal vision.

FIGURE 1 - Dispersion of participants' age (orange diamonds). Average (green line)

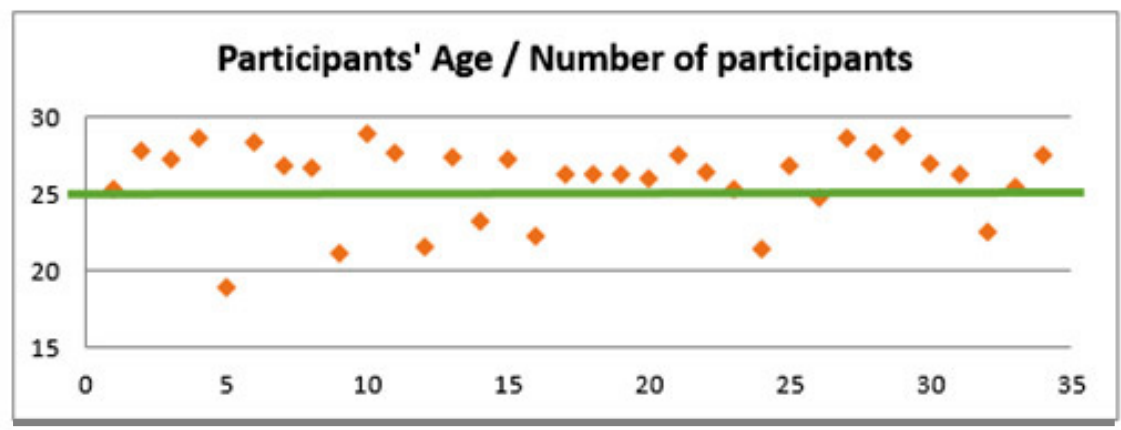

The experiment had a factorial design of $2 \times 2$, with 4 conditions. There were two independent variables related to the semantics of the noun in the subject position: non-specific, here named Control (CT), and kind-denoting, here named, World Knowledge (WK); each one had

${ }^{2}$ This project was submitted to the ethics committee by Professor Antonio Fernando Catelli Infantosi, a brilliant and most esteemed signal processing scholar from COPPEUFRJ, co-author of this study, who died in 2016. 
two levels: congruous (C) and incongruous (I). This design gave rise to four conditions: CTCC; CTIC; WKCC; WKIC. The stimuli in each of these conditions were designated to participants according to a withinsubject distribution.

There were 160 experimental sentences divided among the four conditions. So there were 40 sets of stimuli like that in Table 1. Since there were four conditions, the within-subject distribution demanded we assigned participants to one of four test versions, so that participants did not see the same stimuli in more than one condition.

Each participant saw 40 experimental sentences, out of a total of 160 experimental sentences used in the test. Each participant was also assigned to 80 distractor sentences (40 congruous and 40 incongruous). All the 120 sentences each participant saw (40 experimental stimuli and 80 distractors), were displayed in a pseudo-random manner in order to perfectly control for sequential effects.

Both the subject and the object in all experimental sentences were introduced by a morphologically open DP (definite article) since proper nouns in Portuguese can be introduced by determiners. So this means that the control and the world knowledge conditions were formed by a DP NP in the place of the subject. The occurrence of masculine and feminine determiners in the subject position was balanced among conditions.

The distractors were pseudo-randomly mixed with the experimental stimuli and were formulated so as not to present only verb-complement selections as those in the target stimuli. For instance, while all experimental sentences included a transitive verb with agentive subjects, some distractors included intransitive verbs or light verbs and adverbials. $^{3}$

\footnotetext{
${ }^{3}$ Some of the distractor sentences were: (i) O José trabalha muito no inverno (he works a lot in the winter); (ii) Ela sempre sorri as bananas verdes (she always smiles the green bananas); (iii) Os supermercados são caros (the supermarkets are expensive); (iv) Os policiais têm penas azuis (the policemen have blue feathers). Sentences of type (i), with pronominal subjects and congruous semantics, were formulated to be distractors for congruous Control condition sentences. Sentences of type (ii), with pronominal subjects and incongruous semantics, were formulated to be distractors for incongruous Control condition sentences. Sentences of type (iii), with content subjects and congruous semantics, were formulated to be distractors for congruous WK condition sentences. Finally, Sentences of type (iv), with content subjects and incongruous semantics, were formulated to be distractors for incongruous WK condition sentences.
} 
In selecting the stimuli, the criteria of word-length in syllables was taken into consideration. As to the frequency assessment, in the absence of a Brazilian Portuguese equivalent to a Cobuild Corpus and Frequency Levels, we resorted to a rating scale assessment, like the Likert scale of 7 levels, in which 1 corresponded to most infrequent and 7 to most frequent (DALMORO; VIEIRA, 2013).

We applied this test to 45 undergraduates of the Engineering school of the Federal University of Rio de Janeiro. We put together a collection of 100 nouns and we tested each one of them as to frequency before we made our stimuli. At the end, we selected only the nouns that achieved scores 6 or 7 by at least $75 \%$ of the participants. One item of the test follows as an illustration of the frequency test:

FIGURE 2 - Likert Scale presented to participants

How frequently do you use the word BABY?

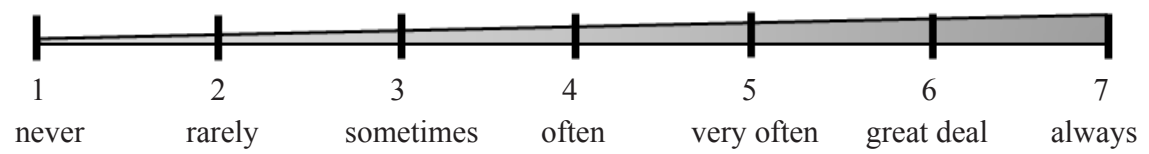

Forty-three out of the 45 respondents (95\%) rated the word bebe (baby) as 6 or 7 in the scale, since they reported using it "a great deal" or "always". Thus, we selected BEBÊ as a suitable word to make one of the stimulus sentences of the test. Contrastingly, the word quadro (painting) was rated as 4 "used often" by $61 \%$ of the respondents, and was, thus, eliminated from the word collection used in the preparation of the experimental stimuli.

TABLE 2 - Additional examples of experimental stimuli in the four conditions

\begin{tabular}{|c|l|}
\hline 2 & \\
\hline CTCC & $\begin{array}{l}\text { O Marcelo apagou o fogo rapidamente } \\
\text { Marcelo put out the fire rapidly }\end{array}$ \\
\hline CTCI & $\begin{array}{l}\text { O Marcelo apagou a alma rapidamente } \\
\text { Marcelo put out the soul rapidly }\end{array}$ \\
\hline WKCC & $\begin{array}{l}\text { O bombeiro apagou o fogo rapidamente } \\
\text { The fireman put out the fire rapidly }\end{array}$ \\
\hline WKIC & $\begin{array}{l}\text { O bombeiro apagou alma rapidamente } \\
\text { The fireman put out the soul rapidly }\end{array}$ \\
\hline
\end{tabular}




\begin{tabular}{|c|c|}
\hline \multicolumn{2}{|r|}{3} \\
\hline СТCC & $\begin{array}{l}\text { A Angela curou o bebê totalmente } \\
\text { Angela healed the baby completely }\end{array}$ \\
\hline CTCI & $\begin{array}{l}\text { A Angela curou o livro totalmente } \\
\text { Angela healed the book completely }\end{array}$ \\
\hline WKCC & $\begin{array}{l}\text { A médica curou o bebê totalmente } \\
\text { The doctor healed the baby completely }\end{array}$ \\
\hline WKIC & $\begin{array}{l}\text { A médica curou o livro totalmente } \\
\text { The doctor healed the book completely }\end{array}$ \\
\hline \multicolumn{2}{|r|}{4} \\
\hline СТCC & $\begin{array}{l}\text { O Antonio puxou a arma na hora } \\
\text { Antonio pulled the gun instantly }\end{array}$ \\
\hline CTCI & $\begin{array}{l}\text { O Antonio puxou a praia na hora } \\
\text { Antonio pulled the beach instantly }\end{array}$ \\
\hline WKCC & $\begin{array}{l}\text { O soldado puxou a arma na hora } \\
\text { The soldier pulled the gun instantly }\end{array}$ \\
\hline WKIC & $\begin{array}{l}\text { O soldado puxou a praia na hora } \\
\text { The soldier pulled the beach instantly }\end{array}$ \\
\hline \multicolumn{2}{|r|}{5} \\
\hline СТCC & $\begin{array}{l}\text { A Fernanda tocou a valsa muito bem } \\
\text { Fernanda played the waltz very well }\end{array}$ \\
\hline CTCI & $\begin{array}{l}\text { A Fernanda tocou o cheiro muito bem } \\
\text { Fernanda played the smell very well }\end{array}$ \\
\hline WKCC & $\begin{array}{l}\text { O músico tocou a valsa muito bem } \\
\text { The musician played the waltz very well }\end{array}$ \\
\hline WKIC & $\begin{array}{l}\text { O músico tocou o cheiro muito bem } \\
\text { The musician played the smell very well }\end{array}$ \\
\hline
\end{tabular}

\subsection{The stimulation protocol}

Stimulus sentences were presented kinetically, word-by-word, on the computer screen, commanded by a script written in Presentation 0.5 (Neurobehavioral Systems, Albany, USA). Participants read test instructions on the screen followed by a warm-up drill that checked their comprehension of the protocol. After the warm-up, participants could receive additional coaching from the experimenter, in case doubts about the protocol still lingered. When ready, participants would start the congruity judgment test, that followed the timeline in Figure 3. 
FIGURE 3 - The timeline of the experiment

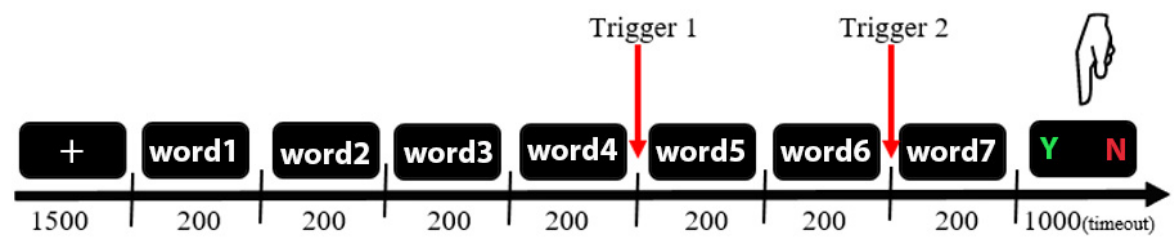

Each word was centrally displayed on the monitor for $200 \mathrm{~ms}$, formatted with white, 14-point, Times New Roman font over a black screen (170 monitor with a 1024 X 768 resolution). At the onset of the display of words 5 and 7, a trigger (square wave) was sent via parallel port to the computer that controls the experiment. This trigger is coupled to the waves sent by the EEG in a way to visually label them.

After the presentation of the last word of each sentence, subjects were to judge the stimulus for incongruence or congruence by pressing either the red $\mathrm{N}$ or green $\mathrm{Y}$ keys that are special keys that are placed on top of two regular keys in the computer keyboard, respectively to respond to the stimuli ( $c f$. Figure 4).

FIGURE 4 - The keyboard with two specially identified keys, respectively for $\mathrm{Y}$ and $\mathrm{N}$ responses

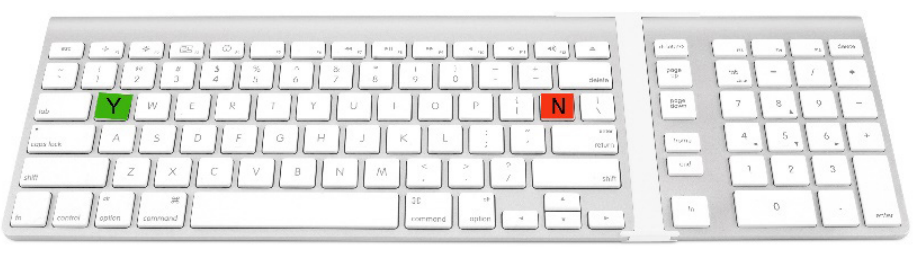

This task allowed us to verify if participants were engaged in the experiments and were reading the sentences attentively. The high rate of correct responses in this off line test might indicate that participants were in fact distinguishing between congruous and incongruous stimuli. Response wait would time-out after $1000 \mathrm{~ms}$. Following the event of judgment or time-out, a white fixation cross was displayed for $1500 \mathrm{~ms}$ before the first word of the next sentence was presented. 


\subsection{EEG Acquisition}

EEG signal was continuously recorded during the whole experimental session from 20 monopolar derivations. Silver-tip electrodes were topographically positioned according to the International 10-20 System (Jasper, 1958), with averaged mastoid reference and ground at FPz.

Electrode impedance was controlled to normal values (for EEG, lower than $5 \mathrm{k} \Omega$ ). Signal was amplified (gain $=18,000)$ and treated with low-pass (cut-off frequency of $32 \mathrm{~Hz}$ ) and high-pass filtering $(0.8 \mathrm{~Hz})$. This filter allows the removal of all slow and constant electrical waves from the signals. All EEG derivations were digitized with a sampling frequency of $1000 \mathrm{~Hz}$ (12-bit analog-to-digital resolution) and were stored for off-line processing.

\subsection{ERP Waveform Estimation}

The multi-channel EEG digital processing of all experimental sentences was performed using Matlab version 5.2 environment (The MathWorks, Inc., MA). The original signal of each subject was segmented into epochs from $500 \mathrm{~ms}$ before up to $1500 \mathrm{~ms}$ after the onset of the target words. Then, an algorithm for artifact rejection was applied to each signal epoch. This algorithm consisted of comparing each EEG sample to a threshold, defined as 1.35 times the Root Mean Squared (RMS) value of an artifact-free individual EEG raw signal. The epochs that presented, within the time interval $0-800 \mathrm{~ms}, 10 \%$ of all samples or $5 \%$ of consecutive samples with absolute value above this threshold were discarded.

The ERP was then estimated by coherently averaging the epochs relative to congruous (or incongruous) EEG response for each topographic derivation of a subject. Hence, ERPs were time-locked to the onset of the stimulus-trigger for each of the two conditions (congruous and incongruous). A $100 \mathrm{~ms}$ pre-stimulus period was used to correct the baseline of each epoch. Individual ERPs were then low-pass filtered (cutoff frequency of $7 \mathrm{~Hz}$, 2nd order Butterworth, applied bi-directionally for obtaining null phase frequency-response, i.e. no phase distortion, and consequently no change in latency). Figures 5 and 6 show the resulting grand-average of the 34 individual ERPs, from 100ms before up to $1000 \mathrm{~ms}$ after the trigger word, where thick and thin lines refer to incongruous and congruous sentences respectively. Negative waves are plotted upward in accordance with ERP literature. 


\section{Results}

FIGURE 5 - Grand-average ERPs from 34 right-handed subjects submitted to the Standard Condition

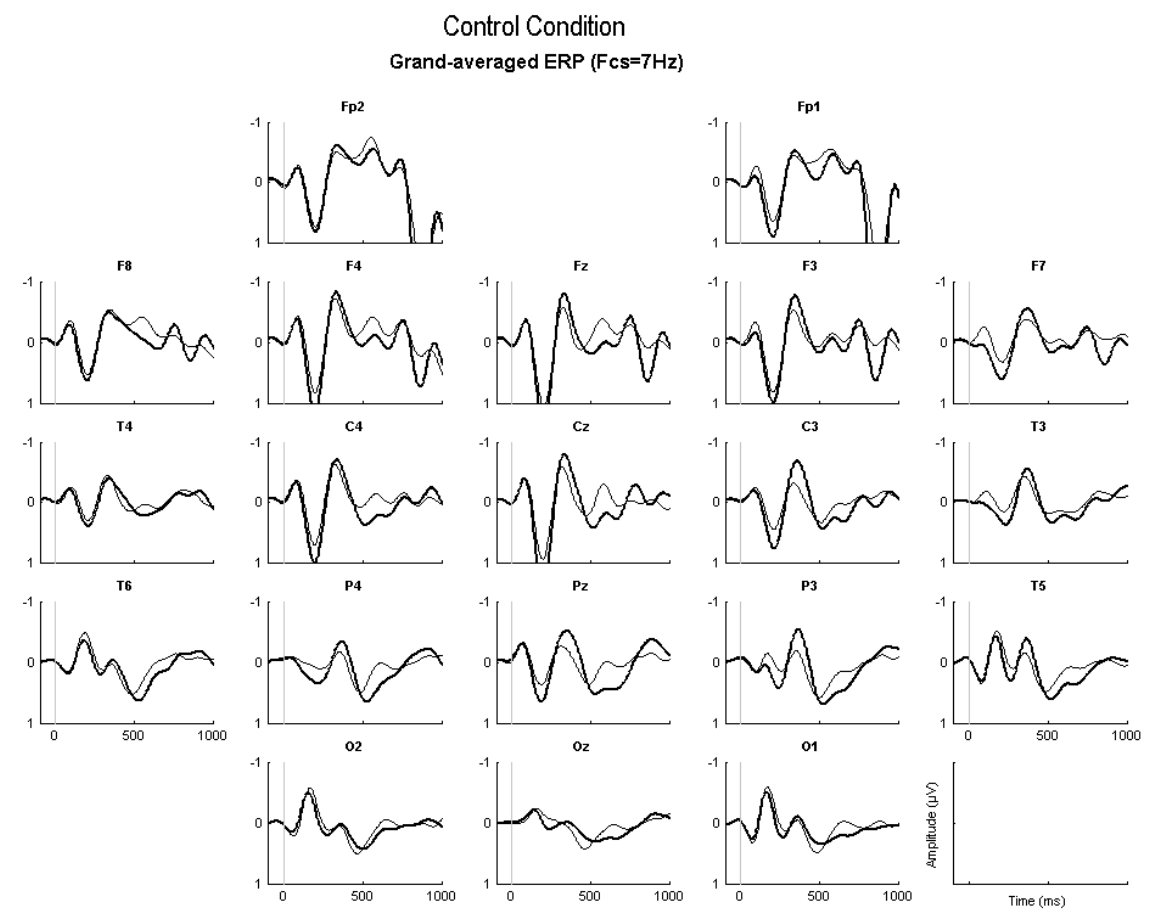

Note: EEG was extracted from 20 different cortical regions, in accordance with the International 10-20 System and with averaged mastoid reference (medial line: Fz, Cz, Pz and Oz; Fp2, F4, F8, C4, T4, P4, T6, O2 and their homologous). The thin line refers to ERPs resulting from congruous sentences and the thick line to those of the incongruous ones. Negativity is plotted upwards. 
FIGURE 6- Grand-average ERPs from 34 right-handed subjects submitted to the Standard

\section{World Knowledge Condition}

Grand-averaged ERP $(\mathrm{Fcs}=7 \mathrm{~Hz})$

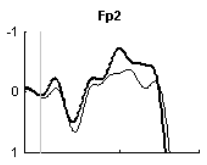

F4
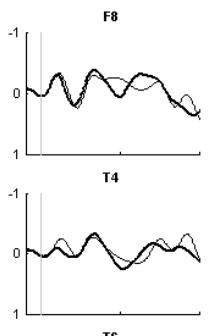

T6
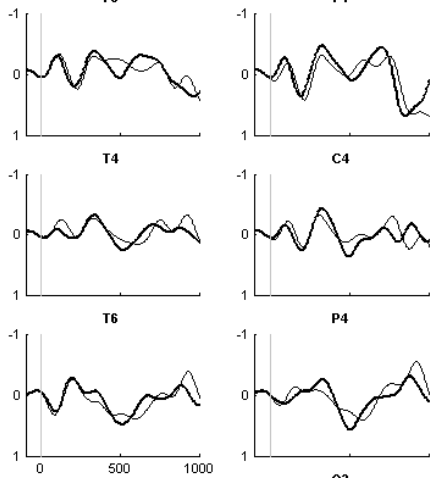

P4
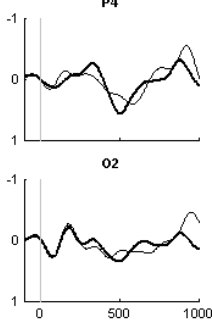

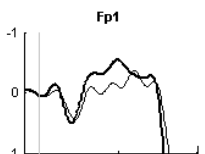

Fz

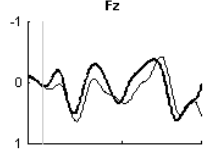

$\mathrm{Cz}$

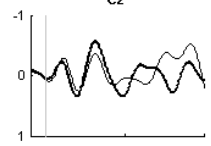

Pz
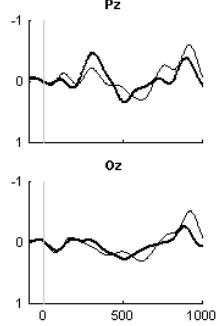

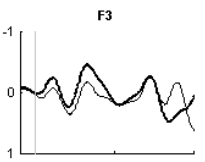

c3

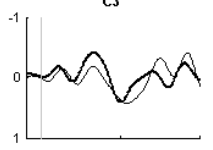

P3

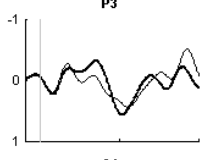

01

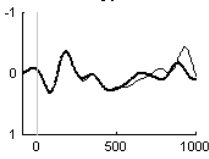

F7
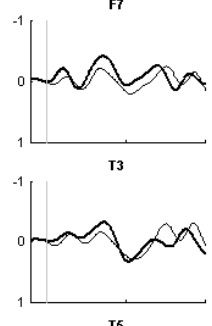

T5
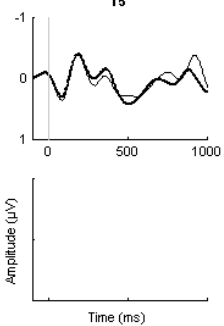

Condition. EEG was extracted from 20 different cortical regions, in accordance with the International 10-20 System and with averaged mastoid reference (medial line: Fz, Cz, Pz and Oz; Fp2, F4, F8, C4, T4, $\mathrm{P} 4, \mathrm{~T} 6, \mathrm{O} 2$ and their homologous). The thin line refers to ERPs resulting from congruous sentences and the thick line to those of the incongruous ones. Negativity is plotted upwards.

\subsection{Wave Morphology Reading}

Since there are specific cerebral regions that respond to specific linguistic stimuli, the manipulation we introduced through the careful streamlining of the stimulus sentences in each condition affected mainly a specific cerebral region: the left centro-parietal derivations. To make interpretation of the ERPs easier to follow, we prepared Figures 7 and 
8 that show the congruous - incongruous contrast in ERPs picked by electrodes that were positioned in this left centro-parietal region of interest.

FIGURE 7 - ERPs in the Control Condition in 4 derivations of interest
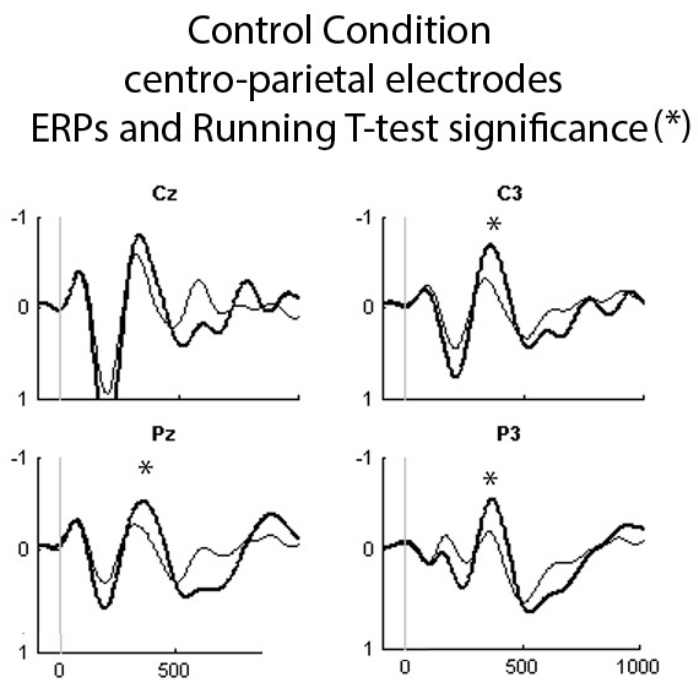

Legend: Thin line is congruous and thick line incongruous, the stars stand for statistically meaningful wave contrast.

In terms of latency, in the Control Condition (Figure 7), the amplitude of the incongruous $\mathrm{N}_{400}$ wave (thick line) is higher than that of the congruous one. Concerning the overall morphology, congruous and incongruous show similar shapes. Notice also that this condition yields basically one ERP within the 400-800 ms window. 
FIGURE 8 - ERPs in the World Knowledge in 4 derivations of interest

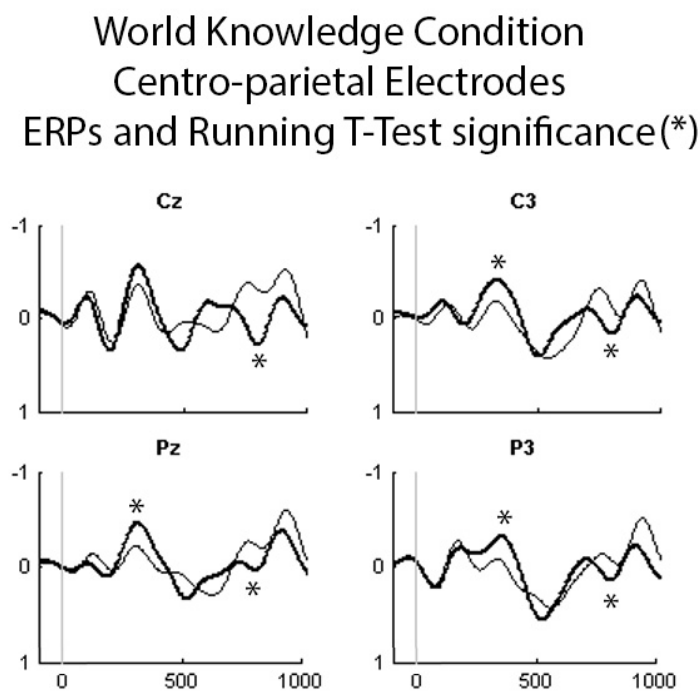

Legend: Thin line is congruous and thick line incongruous, the stars stand for statistically meaningful wave contrast.

In terms of latency, in the World Knowledge Condition (Figure 8), the amplitude of the incongruous $\mathrm{N}_{400}$ wave (thick line) is higher than that of the congruous one. Concerning the overall morphology, congruous and incongruous show similar shapes. Notice also that this condition yields basically two ERPs within the 400-800 ms window. At around $400 \mathrm{~ms}$, derivations with the largest amplitude make up an early $\mathrm{N}_{400}$ peak varying topographically from 300 to $375 \mathrm{~ms}$. On the other hand, in the Control condition, the $\mathrm{N}_{400}$ exhibits a smaller topographical variability (range of 330-377 ms) (Figure 8). Beyond the $\mathrm{N}_{400}$, in the WK condition we also find a positive potential (cf. Cz, Pz, P3), that deepens at around 560-620 ms, whose amplitude is considerably larger in the incongruous stimuli. This second wave is absent in the Control Condition. The amplitude of the incongruous $\mathrm{N}_{400}$ is also higher than that of the congruous one, but the ERP waveforms particularly in P3, Pz and P4 show noticeable differences. 


\subsection{Statistical Reading}

Although there are considerable latency differences between the Control and $\mathrm{WK} \mathrm{N}_{400}$ ERPs (cf. Figures 7 and 8, Table 3), there is no evident difference in the $\mathrm{N}_{400}$ latency between congruous and incongruous ERP within each condition. Therefore, no statistical comparison was performed related to $\mathrm{N}_{400}$ latency. Nevertheless, a comparison of $\mathrm{N}_{400}$ instantaneous amplitude between individual ERPs from incongruous $(I)$ and congruous $(C)$ sentences in each condition was carried out by means of the Running $t$-Test (HAGOORT et al., 2004).

TABLE 3 - Intervals in which the waveforms for incongruous and congruous sentences differ significantly (between brackets).

\begin{tabular}{|c|c|c|c|c|}
\hline Derivation & $\begin{array}{l}\text { Control Latencies } \\
\text { in ms }\end{array}$ & $\begin{array}{l}\text { Control } \\
\text { Waves }\end{array}$ & $\begin{array}{c}\text { WK } \\
\text { Latencies } \\
\text { in ms }\end{array}$ & $\begin{array}{l}\text { WK } \\
\text { Waves }\end{array}$ \\
\hline $\mathrm{T} 3$ & [345-460] & тз & $\begin{array}{l}{[365-430]} \\
{[715-790]}\end{array}$ & ז3 \\
\hline T5 & [505-725] & T5 & [370-410] & тs \\
\hline F3 & [315-430] & $F_{3}$ & [255-420] & F3 \\
\hline $\mathrm{C} 3$ & [315-440] & & $\begin{array}{l}{[310-435]} \\
{[535-620]}\end{array}$ & \\
\hline P3 & [315-455] & & $\begin{array}{l}{[315-443]} \\
{[765-800]}\end{array}$ & \\
\hline $\mathrm{T} 4$ & [410-440] & T4 & {$[625-670]$} & Ta \\
\hline
\end{tabular}




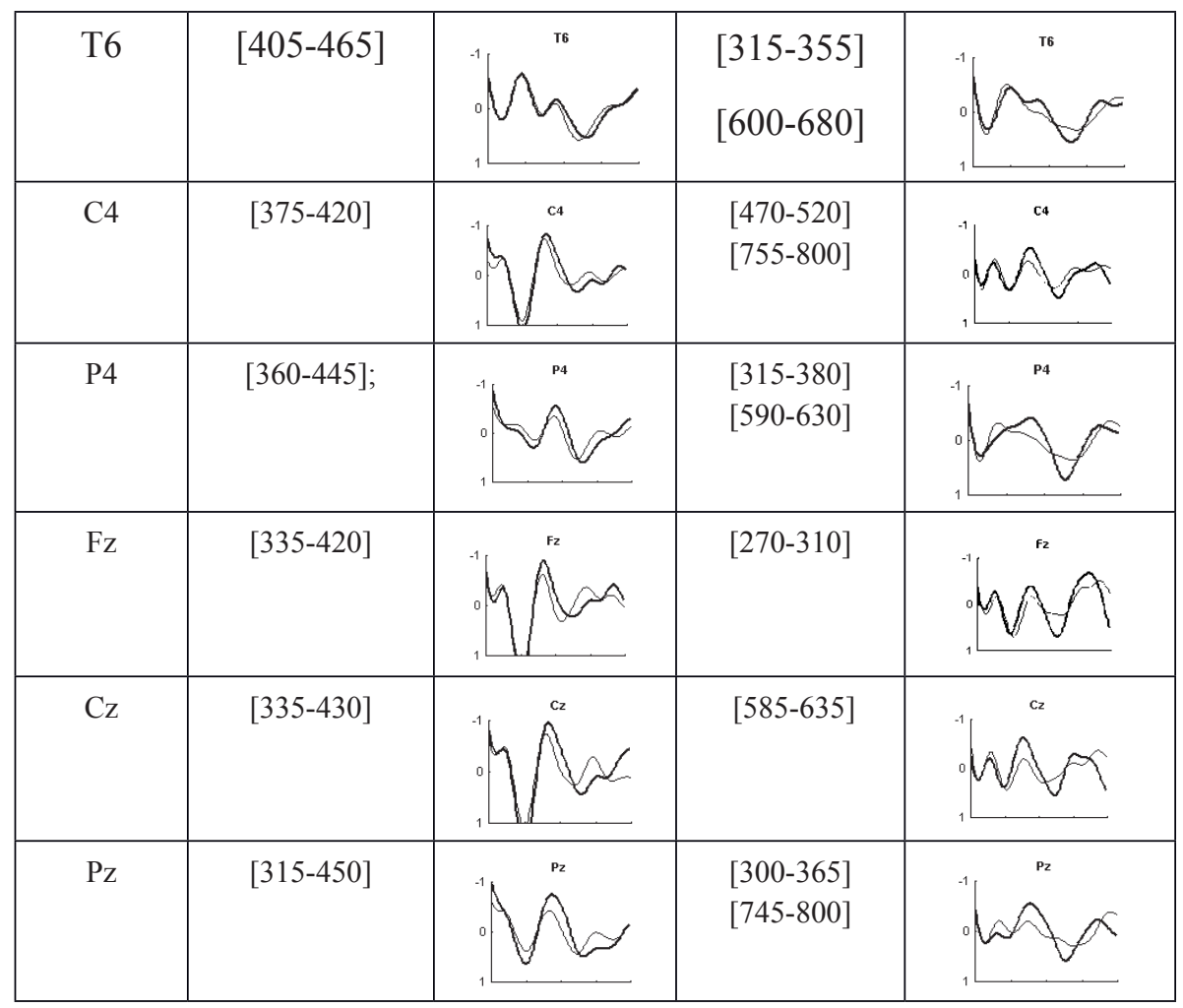

Note: The wave thumbnails are just to illustrate the ERP tendencies within the time interval, not supposed to be used for wave morphology inspection. For better visualization of the morphology of the waves, $c f$. Figures 4 and 5.

Using the differential waveform (I-C), Gaussianity could be assumed and the $t$-test was then applied sample-by-sample (each $5 \mathrm{~ms}$ ) within the time interval of interest, that is from 200 to $800 \mathrm{~ms}$. Two one-sided tests comparing $(I-C)$ to zero, i.e. the null hypothesis of zero difference, were performed using a significance level of $2.5 \%$ for each side. At a given instant of time, if the null hypothesis is rejected for the positive side, one can infer that the resulting grand-average for incongruous sentences is statistically more positive or less negative than that for congruous sentences. The counterpart reasoning is applied to the instants of time for which the null hypothesis is rejected for the negative side. 
Table 3 shows the intervals when the waveforms for incongruous and congruous sentences differ (between brackets). For example, in Pz, the time intervals [315-450] ms for Control condition and [300-365] ms for WK indicate more negativity for incongruous waveforms (thick lines) than for congruous (thin lines). Similar results, indicating that N400 is statistically more pronounced due to incongruence, are noted in most derivations except for Fp1, Fp2, F7, F8, T3 and C4 in the Control condition and $\mathrm{O} 1$ in the WK one. Further, an earlier N400 occurs in the WK if compared to Control condition. In Pz, the interval [745-800] ms for WK condition exhibits a more pronounced positivity for incongruous waveforms. The same kind of positivity is observed in other derivations except for Fp1, Fp2, Fz, F3, F7, T4, T5 and O2.

\section{Discussion}

The most interesting finding revealed by this experiment is that the sentences in the Control conditions yielded only one ERP, the $\mathrm{N}_{400}$, while those in the World Knowledge conditions yielded two, respectively the $\mathrm{N}_{400}$ and the $\mathrm{P}_{600}$. In fact, other studies (LAGE, 2005; COWLES; KUTAS; KLUENDER, 2003; VAN BERKUM et al., 2003; HAGOORT et al., 2004) have found similar ERP results reporting an anterior negativity $\left(\mathrm{N}_{400}\right)$ coupled with $\mathrm{P}_{600}$ effects in the establishment of anaphoric links involving world knowledge introduced by the subject. But we found no studies that streamlined conditions so as to properly compare a sentence with poor world knowledge content with the exact same sentence with an NP that deployed a rich pragmatic frame.

The syntax-first assumption that the course of the derivational process starts with the bottom merge does not completely conform with the results we found, since it cannot be applied to each and every sentence with a transitive verb. In our experiment, the World Knowledge stimuli that have a kind-denoting DP in the subject position, hastened the computational course. So it means that some information was indeed sensed linearly, as soon as the kind denoting subject entered the computation.

Nevertheless, the idea that the frame established by the subject would completely shape the general understanding of the sentence did not hold true either. Notice the contrast pull the tooth Vs pulled the thunder. This contrast was effective both for the Control and for the WK 
conditions. In both conditions we have a large amplitude $\mathrm{N}_{400}$ relative to the incongruous version. But only in the WK condition is there a $\mathrm{P}_{600}$ relative to the incongruous condition. So, it is clear that the lexical, semantic and pragmatic components of the DP in the subject position of the WK condition are only fully digested at the end of the computation of the sentence, with the $\mathrm{P}_{600}$ So, if information introduced by the subject, that comes in first, can only be sensed at $600 \mathrm{~ms}$ and information about the vP merge can be sensed at $400 \mathrm{~ms}$, this reveals that there is precedence of some information of the $\mathrm{vP}$ merge in relation to some information stemming from the subject.

These facts are indicative that the linear online order of processing has to interact with the derivational phases of grammar that are available in the brain. So, in an itemized way, here are the conclusions.

a. Concerning the syntactic computation, in the WK condition, incongruence is established by the integration of the subject after the verbobject merge. That is, in this condition, our prediction is that incongruence is established later in the derivation, at the subject-predicate merge.

b. Concerning the Mental representation of contents, to judge the congruence of the control condition sentences, we have to know the semantic selectional properties of the verbs. For instance, extinguish selects an object with the semantic property of fire; heal selects an object with the semantic property of living being. In the incongruous version of the control condition (CTCI), semantic anomaly is established by and limited to the lower merge.

In the WK condition, incongruity judgments include information introduced by the subject merge, conforming to representations of world facts, including the notion, for instance, that a dentist pulls tooth, a fireman extinguishes fire. So, the incongruity in such cases stem from the subject merge and requires World Knowledge with special scenarios, which may encompass actual facts like treating a patient or putting out a fire or make-believe conventions like spinning a web for fictional characters like Spiderman, inserted in what has been termed a Possible World Box (NICHOLS; STICH, 2000).

A semantic anomaly like eat shoes produces an incongruous electric effect with a latency of about $400 \mathrm{~ms}$ and a large amplitude, the $\mathrm{N}_{400}$, an effect that has been widely attested in the ERP literature and, in our work, was statistically indicated by means of a running $t$-test $(\alpha=0.05)$. This electric effect is said to result from difficulty of verb- 
object integration: for instance shoes with its property [leather artifact] would not be selected by eat. The stimuli composed for experiments usually have the poorest content subjects possible, like a pronoun, any proper name or a non-specific kind (man, woman, boy etc), for instance. Thus, the subjects chosen for the Control Condition stimuli were clearly less restrictive than those picked for the WK condition. For instance, dentist is a fixed reference with defined objectives clothes, actions and origin while, a man or Donald can be any male human.

c. Concerning the contrast between the two conditions described above, the first finding we intend to discuss is the difference in latency between the first electrical wave in the Control condition and that in the $\mathrm{WK}$ one. Look at the $\mathrm{N}_{400}$ latencies in the Control condition and compare them to those in the WK condition, presented in Table 3. Note that the $\mathrm{N}_{400}$ related to the vP-object merge in the WK condition is earlier than that in the Control condition. How can we explain the fact that a verbobject merge involving special World Knowledge contents hastens the course of the derivation?

In the processing of Brazilian Portuguese, an SVO (subject-verbobject) word order language, prior to the verb-complement computation, there is the linear precedence of the subject. For the subject to be saved until syntactic computation integrates it into the structure being formed, it has to be stored in short term memory. For that, lexical access is required. And lexical access is automatic to allow whatever cognitive handling is needed, including storing.

If we look at the first NP as a transitorily independent expression, whose lexical access will guarantee memory storage of content for later use, we can suppose that the lexical content accessed is not completely innocuous to on-going syntactic computation and, in fact, affects the processing of the verb-complement constituent. If this is the case, the presence of a subject that recruits a non-default context hastens syntactic processing because it poses special requirements that restrict the VP internal selections.

d. Concerning the $\mathrm{P}_{600}$, a second ERP that deepens at about $600 \mathrm{~ms}$ in incongruous sentences of the WK condition ( $c f$. Table 3, WK derivations at T3, P3, T6, C4, P4, Fz, Cz and Pz). Our interpretation is that this positivity exclusive to this condition, is related to the repair efforts to integrate contents from kind-denoting DPs into the on-going subject-VP merge. We assume here that the integration of this kind of DP with the 
vP constituent is a two-fold operation: first it prompts an early semantic access that accelerates the vP merge, but this early independent lexical access does not spare the later full computation required to merge the subject with the vP, which can be seen in the $\mathrm{P}_{600}$ component.

We are hereby challenging the frame analysis that the subjectobject semantic synergy spares the language user from making the regular syntactic computations to effect the vP-object merge operation. Our claim is that the array of NP candidates potentially licensed at the vP merge is much restricted in view of the access to a world-constructing non-default subject.

e. Concerning the higher wave amplitudes of the object merge coming from the congruous and incongruous sentences in the WK condition, a similar amplitude effect was reported by Hagoort et alii. (2004) in the gamma radiation related to stimuli requiring World Knowledge processing. ${ }^{4}$ Knowing that amplitude is a parameter related to a difficulty to perform morpho-syntactic integration (KUTAS; HILLYARD, 1984; FONTENEAU; FRAUENFELDER; RIZZI, 1998; HOLCOMB; NEVILLE, 1991), we propose that the pragmatic scope set by the subject DPs in the WK condition presented extra selectional restrictions to the verb, which ultimately overburdened the verbobject integration, causing the higher wave amplitudes captured at the derivations. Since the introduction of the subject shapes the causation mode in the VP(PYLKKÄNEN, 2002; MARANTZ, 2001), the retrieval of the subject DP requires encyclopedic contents, and so way more cognitive resources are demanded.

\footnotetext{
${ }^{4}$ Hagoort et alii (2004) examined the wavelet band of theta and gamma radiation in relation to retrieval and usage of world knowledge and of knowledge of word meaning encoded in sets of stimuli with congruity violations. The authors found greater gamma electric activity as the oscillatory brain responses in relation to the world knowledge violations and greater theta activity in relation to the purely semantic conditions. Despite the fact that the former finding is compatible with our ERP findings, a direct comparison between the two experiments cannot be made since Hagoort et alii. used light verbs in the stimuli: Dutch trains are yellow / white / sour. Light verbs do not impose selectional restrictions confined to the vP level. As to latency, the authors explain that the wavelet transform cannot be a reliable measure of temporal resolution, thus, we cannot compare their latencies with ours.
} 


\section{Conclusion}

This comparative ERP analysis of time-locked stimuli brought about an unexpected result: an $\mathrm{N}_{400}$ that is earlier in the WK Condition than in the Control Condition (running $t$-test, $(\alpha=0.05)$. We also observed that, concerning congruity, the incongruous sentences in the WK condition generated more pronounced effects on the ERP morphology than those in the Control condition. These results can be properly interpreted if we take into account that access to the subject and its storing for future syntactic computation will entail a regular or modified array of verb semantic selection restrictions. Entering a nontrivial world knowledge space causes three effects in the waves locked to vP processing: $\mathrm{N}_{400}$ waves coming from the $\mathrm{WK}$ Condition are faster and more pronounced than those in the Control condition, the special semantic content of subjects in the WK condition impose a further integration, $\mathrm{P}_{600}$, that can only take place after the verb is fully merged with its object (bottom-up order). The $\mathrm{P}_{600}$ might be related to the repair efforts to integrate special contents into the on-going subject-vP merge. This extended computation is not necessary for the Control condition because the special merge between verb and object is not added of any special world knowledge meaning.

\section{Acknowledgments}

Aniela Improta França gratefully acknowledges the financial support to her research (PQ 312079/2016-8) from CNPq, Brazil (National Counsel of Technological and Scientific Development).

\section{References}

ALTMANN, G.; STEEDMAN, M. Interaction with context during human sentence processing. Cognition, Elsevier, v. 30, p.191-238, 1988.

ALTMANN, G.; KAMIDE, Y. Incremental interpretation at verbs: Restricting the domain of subsequent reference. Cognition, v. 73, p. 247264, 1999.

CHOMSKY, N. A minimalist program for linguistic theory. In: ed. HALE, K.; KEYSER, S. The view from building 20: Essays in honor of Sylvain Bromberger. Cambridge, Mass: MIT Press, 1993. p. 1-52. 
CHOMSKY, N. Minimalist inquiries: the framework. MIT Working Papers in Linguistics. Cambridge, MA: MIT 1998.

CHOW, W.-Y.; PHILLIPS, C. No semantic illusions in the "Semantic P600" phenomenon: ERP evidence from Mandarin Chinese. Brain Research, Elsevier, v. 1506, p. 76-93, 19 abr. 2013.

CLARK, H. H.; SENGUL, C. J. In search of referents for nouns and pronouns. Memory and Cognition, Springer, v. 7, p. 35-41, 1979.

COWLES, H. W.; KUTAS, M.; KLUENDER, R. Different ERP results from identical sentences: The importance of prior context in sentence processing. In: ANNUAL CUNY CONFERENCE ON HUMAN SENTENCE PROCESSING, $16^{\text {th }}$., Cambridge, 2003. Cambridge, MA.: Massachusetts Institute of Technology, 2003. Poster presented.

DALMORO, M.; VIEIRA, K. M. Dilemas na construção de escalas Tipo Likert: o número de itens e a disposição influenciam nos resultados. Revista Gestão Organizacional, UnoChapecó, v. 6, n. 3, p. 161-174, 2013.

FEDERMEIER, K. D. Thinking ahead: the role and roots of prediction in language comprehension. Psychophysiology, Wiley Online Library, v. 44, p. 491-505, 2007.

FERREIRA, F.; CLIFTON, C. The independence of syntactic processing. Journal of Memory and Language, Elsevier, v. 25, p. 348-368, 1986.

FILLMORE, C. Frame semantics. In: The Linguistic Society of Korea (Ed.). Linguistics in the Morning Calm: Selected Papers from SICOL-1981. Seoul, Korea: Hashin Publishing Co., 1982. p. 111-137. [Reprinted in: GEERAERTS, D. (Ed.). Cognitive Linguistics: Basic Reading. Berlin: Mouton de Gruyter, 2006.]

FILLMORE, C. Valency issues in FrameNet. In: HERBST, T.; GÖTZVOTTELER, K. (Ed.). Valency: Theoretical, Descriptive and Cognitive Issues. Berlin: Mouton de Gruyter, 2007. p. 129-160.

FILLMORE, C.; BAKER, C. Frames approaches to semantics analysis. In: HEINE, B.; NARROG, H. (Ed.). Oxford Handbook of Linguistic Analysis. Oxford: Oxford University Press, 2010. p. 313-340.

FONTENEAU, E.; FRAUENFELDER, U.; RIZZI, L. On the contribution of ERPs to study of language comprehension. Bulletin Suisse de Linguistique Appliquée: Etudes en neurolinguistique, Association Suisse de Linguistique Appliquée (ASLA), v. 68, p. 111-124, 1998. 
FRANÇA, A; LEMLE, M; CAGY, M; CONSTANT, P; INFANTOSI, A F. Discriminating among different types of verb-complement merge in Brazilian Portuguese: an ERP study of morphosyntactic sub-processes. Journal of Neurolinguistics, Elsevier, v. 17, p. 425-437, 2004.

FREUNBERGER, D.; ROEHM, D. Semantic prediction in language comprehension: evidence from brain potentials. Language, Cognition and Neuroscience, Taylor \& Francis Online, v. 31, n. 9, p. 1193-1205, 2016. http://dx.doi.org/10.1080/23273798.2016.1205202.

FRIEDERICI, A. D. The time-course of syntactic activation during language processing: A model based on neuropsychological and neurophysiological data. Brain and Language, Elsevier, v. 50, p. 259281, 1995.

GOMES, J. N. Investigating the dissociation between $N_{400}$ and $P_{600}$ effects on the syntax semantics interface: an ERP study. 2014. 183f. Tese (Doutorado) - Faculdade de Letras, da Universidade Federal do Rio de Janeiro, Rio de Janeiro, 2014.

GOMES, J.; FRANÇA, A. I. A técnica de ERP: Investigando a assimetria sujeito-objeto na interface sintaxe-semântica com EEG. Letras de Hoje (Online), PUCRS, v. 4, p. 152-163, 2015.

GOUVEA, A. C. et al. The linguistic processes underlying the P600. Language and Cognitive Processes, Taylor \& Francis Online, v. 25, n. 2, p. 149-188, Feb. 2010. ISSN 0169-0965.

HAGOORT, P; HALD, L; BASTIAANSEN, M. PETERSSON, K. $\mathrm{M}$. Integration of word meaning and world knowledge in language comprehension. Science, American Association for the Advancement of Science, v 304, p.438-441, April 2004.

HAVILAND, S. E.; CLARK, H. H. What's new? Acquiring new information as a process in comprehension. In: ALTMANN, G. T. M. (Ed.). Psycholinguistics: Critical concepts in psychology. London: Routledge, 2002. p. 512-521.

HOLCOMB, P. J.; NEVILLE, H. J. Natural speech processing: an analysis using event-related brain potentials. Psychobiology, Elsevier, v. 19, p. 286-300, 1991. 
ITO, A.; PICKERING, M. J.; MARTIN, A. E.; NIEUWLAND, M. S. Predicting form and meaning: Evidence from brain potentials. Journal of Memory and Language, Elsevier, v. 86, p. 157-171, 2016. doi:10.1016/j. jml.2015.10.007.

KIM, A.; OSTERHOUT, L. The independence of combinatory semantic processing: Evidence from event-related potentials. Journal of Memory and Language, Elsevier, v. 52, n. 2, p. 205-225, Feb. 2005.

KOS, M; VOSSE T.; VAN DEN BRINK, D.; HAGOORT, P. About Edible Restaurants: Conflicts between Syntax and Semantics as Revealed by ERPs. Frontiers in Psychology, Fontieres Media, v. 1, p. 1-11, Jan. 2010.

KUPERBERG, G. R.; KREHER, D; SITNIKOVA, T.; CAPLAN, D.; HOLCOMB, P. The role of animacy and thematic relationships in processing active English sentences: evidence from event-related potentials. Brain and Language, Elsevier, v. 100, n. 3, p. 223-237, mar. 2007.

KUTAS, M.; HILLYARD, S. A. Reading senseless: brain potentials reflect semantic incongruity. Science, American Association for the Advancement of Science, v. 207, p. 203-205, 1980.

KUTAS, M.; HILLYARD, S. A. Brain potentials during reading reflect word expectancy and semantic association. Nature, v. 307, Springer Nature, n. 5947, p. 161-163, 1984.

KUTAS, M.; LINDAMOOD, T. E.; HILLYARD, S. A. Word expectancy and event-related brain potentials during sentence processing. In: KORNBLUM, S.; REQUIN, J. (Ed.). Preparatory studies and processes. Hillsdale, NJ: Erlbaum. 1984. p. 217-237.

LAGE, A. C. Aspectos neurofisiológicos do processamento de sentença em português. 2005. Tese (Doutorado) - Universidade Federal do Rio de Janeiro, Rio de Janeiro, 2005.

LAU, E. Lau; STROUD, C.; PLESCH, S.; PHILLIPS, Colin. The role of structural prediction in rapid syntactic analysis. Brain and Language, Elsevier, v. 98, n. 1, p. 74-88, Jul. 2006.

LI, X.; YANG, Y.; HAGOORT, P. Pitch accent and lexical tone processing in Chinese discourse comprehension: an ERP study. Brain Research, Elsevier, v. 1222, 192-200, 2008. doi:10.1016/j.brainres.2008.05.031 
MARANTZ, A. Words. (MS Word document). Handout from WCCFL XX, 2001.

NICHOLS, S.; STICH, S. A cognitive theory of pretense. Cognition, New York, Elsevier, v. 74, n. 2, p. 115-147, 2000.

PHILLIPS, C.; LEWIS, S. Derivational Order in Syntax: Evidence and architectural consequences. In: CHESI, C. (Ed.). Directions in Derivations. Amsterdam: Elsevier, 2009. v. 2, p. 427-459.

PYLKKÄNEN, L. Introducing Arguments. 2002. Thesis (Ph.D.) - MIT, Cambridge, MA., 2002.

SCHUBERTH, R. E.; EIMAS, P. Effects of context on the classification of words and nonwords. Journal of Experimental Psychology: Human Perception and Performance, American Psychological Association, v. 3, p. 27-36, 1977.

STANOVICH, K. E; WEST, R. F. The effect of sentence context on ongoing word recognition: Tests of a two-process theory. Journal of Experimental Psychology: Human Perception and Performance, American Psychological Association, v. 7, p. 658-672, 1981.

STOCKALL, L.; MARANTZ, A. A single route, full decomposition model of morphological complexity: MEG evidence. The Mental Lexicon, John Benjamins, v. 1, n. 1, p. 85-123, Jan. 2006.

VAN BERKUM, J.; BROWN, C. M.; HAGOORT, P.; ZWITSERLOOD, P. Event-related brain potentials reflect discourse-referential ambiguity in spoken language comprehension. Psychophysiology, Wiley Online Library, v. 40, p. 235-248, 2003.

VAN PETTEN, C.; KUTAS, M. Influences of semantic and syntactic context in open- and closed-class words. Memory \& Cognition, Springer, v. 19, p. 95-112, 1991. 
